\title{
Influence of canopy structure on yield of cassava cultivars at various toposequences of an inland valley agro ecosystem
}

\author{
M. T. Lahai ${ }^{1 \star}$, I. J. Ekanayake ${ }^{2,3}$ and J. P. C. Koroma ${ }^{1}$ \\ ${ }^{1}$ Department of Crop Science, Njala Campus, Njala University, PMB, Freetown, Sierra Leone. \\ ${ }^{2}$ Crop Improvement Division, International Institute of Tropical Agriculture (IITA), Oyo Road, PMB 5320, Ibadan, Nigeria. \\ ${ }^{3}$ IBRD, 1850, I-street, Washington DC 20043, USA.
}

Accepted 19 September, 2011

\begin{abstract}
A two-year trial to evaluate differences in canopy parameters in relation to productivity of cassava was conducted in inland valley ecology in a $4 \times 4$ Latin square design. Canopy parameters differed between sites, toposequence positions and years due to large differences in water table depth and weather conditions. Leaf number, leaf formation rate, leaf area index, canopy area and stay green ability correlated positively with yield. The improved cultivars with higher values for these parameters had higher yields than the landraces. However, TMS 4(2)1425 with the highest values had super-optimal, while the landrace produced sub-optimal canopy parameters; both of which reduced the yield. TMS 91/02324 and TMS 91/02327 with intermediate values maintained optimal canopy parameters resulting in high yield. Shallow water table ( 0.20 to $0.45 \mathrm{~m}$ below mound top) and drought reduced the canopy parameters and yield, while well distributed rainfall, high humidity and moderate temperatures (19 to $20^{\circ} \mathrm{C}$ ) improved the canopy parameters and yield. Canopy parameters of low yielding landrace were more susceptible to shallow water table and drought than the high yielding improved cultivars. Selection of cultivars with good maintenance of canopy parameters during mid-season drought and late season excess moisture can contribute to increased tuber yield of cassava in inland valley ecology.
\end{abstract}

Key words: Cassava cultivars, water table depth, drought, excess moisture stress, canopy parameters, tuber yield.

\section{INTRODUCTION}

Cassava is the world's sixth most important crop (Lebot, 2009) and constitutes a staple food for over 700 million people (Njoku et al., 2010). It is a major source of calories in tropical Africa (Burns et al., 2010) due to its adaptability to marginal soils and erratic rainfall, high productivity per unit of land and labour and possibility of supply throughout the year (Nweke et al., 2002). The adaptation to different edapho-climatic conditions (Adeniji et al., 2011) makes cassava a favourite dry season crop grown in inland valleys in West and Central Africa (Lahai and Ekanayake, 2009).

Inland valleys are first and second order small streams that are found at the upper reaches of drainage basins. They are widely distributed in the agro-ecological zones of sub-Saharan Africa and occupy about 130 million hectares of land in inter-tropical Africa (Jalloh, 2003) and

*Corresponding author. E-mail: drmtlahai@yahoo.com. Tel: +232 33816024 . 
25 million hectares in West Africa (Andriesse et al., 1994). Hydrologic regimes of inland valleys influence cropping patterns. During the rainy season, water table rises above the soil surface and farmers grow rice at the valley bottoms. In the dry season, the water table recedes and residual moisture content is inadequate to support a second rice crop and cassava is often grown as a dry season crop (Ekanayake et al., 1994; Jalloh, 2003). As a result of water table fluctuations, the soil undergoes three critical moisture conditions during the growing season of cassava. The water table is above the soil surface at planting period in December to January; recedes deep below the soil surface during the peak of the dry season in March to April; and again rises above the soil surface at harvesting in May to June (Mohamoud, 1994; Lahai and Ekanayake, 2009). Thus, cassava growing in inland valley is subjected to excess moisture stress during early and late season growth stages and to moisture deficit in mid-season. However, cassava has highly responsive stomata, deep root system and effective carbon fixation system for enhanced photosynthesis under drought stress (El-Sharkawy, 1993; Lahai and Ekanayake, 2010). Cassava can therefore tolerate long periods of drought (Tafur et al., 1997; Lebot, 2009), but it is highly susceptible to excessive water (Ande, 2011).

Excess soil moisture resulting in anaerobic conditions leads to restriction in rooting zones, nutrient deficiency, tuber rotting and subsequent poor growth and tuber yield of cassava (Izac et al., 1991; Ande, 2011). Selection of cassava cultivars for adaptation to inland valley ecology gives an indication of tolerance to both excess moisture and drought stress. Such information could be useful in breeding for cultivars that adapted to both upland and inland valley soil conditions.

Study of canopy development is a must to estimate the degree of adaptation of a genotype to the environment in which it is grown. Leaf area index (LAl) is the usual measure of canopy development (Sheriff and Muchow, 1984; Lebot, 2009). LAl depends on the rate of leaf formation per apex, apex number per unit area and leaf size and longevity (Lebot, 2009). High positive correlations exist between root yield and LAI, rate of leaf formation and leaf life (Lahai et al., 1999). However, cassava has simultaneous development of leaf area and tuber, and supply of assimilate is partitioned between growth of leaves and tubers (Lebot, 2009). These results in a delicate, balance between top and tuber growth for maximum yield, with maximal tuber growth occurring at LAl values of 2.5 to 3.5 at which optimum light interception and utilisation occur (Ramanujam, 1985; Lebot, 2009).

Research on cassava canopy structure in relation to yield had focused mainly on cassava grown on the upland where tubers are harvested after 12 months of growth. The results may be different in the case of dry season cultivation in inland valley where dry spell and high light intensity in mid-season and excess moisture in late season are constraints to production. The objective of this study was therefore to evaluate differences in canopy parameters in relation to root yield of four cassava cultivars under inland valley conditions.

\section{MATERIALS AND METHODS}

\section{Site description}

Two small inland valleys, one located at the International Institute of Tropical Agriculture (IITA) research farm at Ibadan $\left(7^{\circ} 30^{\prime} \mathrm{N}\right.$ and $3^{\circ}$ $54^{\prime} \mathrm{E}, 243 \mathrm{~m}$ above sea level (a.s.l.)) and the other on a farmer's field at Alabata $\left(4^{\circ} 46^{\prime} \mathrm{N}\right.$ and $2^{\circ} 34^{\prime} \mathrm{E}, 210 \mathrm{~m}$ a.s.l.) in the forestsavanna transition zone in South-western Nigeria were the test sites. During the trial period, mean minimum temperature $\left({ }^{\circ} \mathrm{C}\right)$, relative humidity $(\%)$ and rainfall $(\mathrm{mm})$ were higher in $2001\left(19.8^{\circ} \mathrm{C}\right.$, $85 \%, 955.9 \mathrm{~mm})$ than in $2002\left(19.1^{\circ} \mathrm{C}, 75 \%, 642.6 \mathrm{~mm}\right)$, but mean maximum temperature $\left({ }^{\circ} \mathrm{C}\right)$, evaporation $(\mathrm{mm})$ and solar radiation $\left(\mathrm{MJ} / \mathrm{m} /\right.$ day) were higher in $2002\left(28.4^{\circ} \mathrm{C}, 962.8 \mathrm{~mm}, 13.49\right.$ $\mathrm{MJ} / \mathrm{m} /$ day) than in $2001\left(27.5^{\circ} \mathrm{C}, 891.1 \mathrm{~mm}, 13.09 \mathrm{MJ} / \mathrm{m} /\right.$ day $)$. The valley bottom soils are classified as Tropaquents (Moormann et al., 1975) having loamy sand at both sites. At Alabata, soil $\mathrm{pH}\left(\mathrm{H}_{2} \mathrm{O}\right)$, organic $\mathrm{C}, \mathrm{N}, \mathrm{P}$ and $\mathrm{K}$ were $3.91,0.99 \%, 0.11 \%, 7.43 \mathrm{mg} / \mathrm{kg}$ and $0.18 \mathrm{cmol} / \mathrm{kg}$ in 2001, respectively; the corresponding values in 2002 were $4.60,0.46 \%, 0.13 \%, 6.80 \mathrm{mg} / \mathrm{kg}$ and $0.20 \mathrm{cmol} / \mathrm{kg}$. The low organic carbon in 2002 as compared to 2001 reflected reduction in organic carbon as a result of decomposition due to continuous cultivation of the same sites for two consecutive years. At Ibadan soil $\mathrm{pH}$, organic $\mathrm{C}, \mathrm{N}, \mathrm{P}$ and $\mathrm{K}$ were $4.87,1.66 \%, 0.15 \%$, $3.75 \mathrm{mg} / \mathrm{kg}$ and $0.08 \mathrm{cmol} / \mathrm{kg}$ in 2001 and $5.40,0.53 \%, 0.13 \%, 2.78$ $\mathrm{mg} / \mathrm{kg}$ and $0.10 \mathrm{cmol} / \mathrm{kg}$ in 2002 , respectively.

\section{Experimental design, plant establishment and water table depth measurement}

At each site, 3 positions were marked out along the toposequence and designated valley fringe, valley intermediate and valley bottom (Figure 1). Each toposequence position had 16 flat-top mounds arranged in a $4 \times 4$ Latin square design. Each mound measuring for a plot was $2 \times 2 \mathrm{~m}$ and $0.6 \mathrm{~m}$ high and was spaced $1 \mathrm{~m}$ apart. Three 2 m-long polyvinyl chloride (PVC) pipes of $0.05 \mathrm{~m}$ in diameter, serving as modified piezometers were buried to a depth of $1.5 \mathrm{~m}$ in furrows between mounds in each position to monitor water table depth on weekly basis. Six stem cuttings each $0.25 \mathrm{~m}$ long with 8 to 10 effective nodes, from mature healthy plants were planted on each mound at a spacing of $1 \mathrm{~m}$ between rows and 0.75 $\mathrm{m}$ between plants. Planting was done at Ibadan and Alabata on 12 February and 12 March 2001 in the first season and on 18 and 24 December 2001 in the second season, respectively. Three improved cultivars (TMS 4(2)1425, TMS 91/02324 and TMS 91/02327) and a landrace (Isunikankiyan) were used. Table 1 describes the genetic characters of the cultivars. Hand weeding was done as required but no fertilizer was applied. The nonapplication of fertilizer was to emulate the local farmers who normally do not apply fertilizer to cassava in inland valleys.

\section{Leaf area, canopy development and stay-green score}

Number, rate of formation (change in number between measurements) and total leaf area (using leaf area meter LI-3000) were used to monitor leaf area development on four tagged plants per plot at bi-weekly intervals. Canopy development was monitored on the same plants using canopy area. Leaf area index (LAl) was calculated as leaf area $\left(\mathrm{m}^{2}\right) /$ ground area $\left(\mathrm{m}^{2}\right)$. The combined effects 


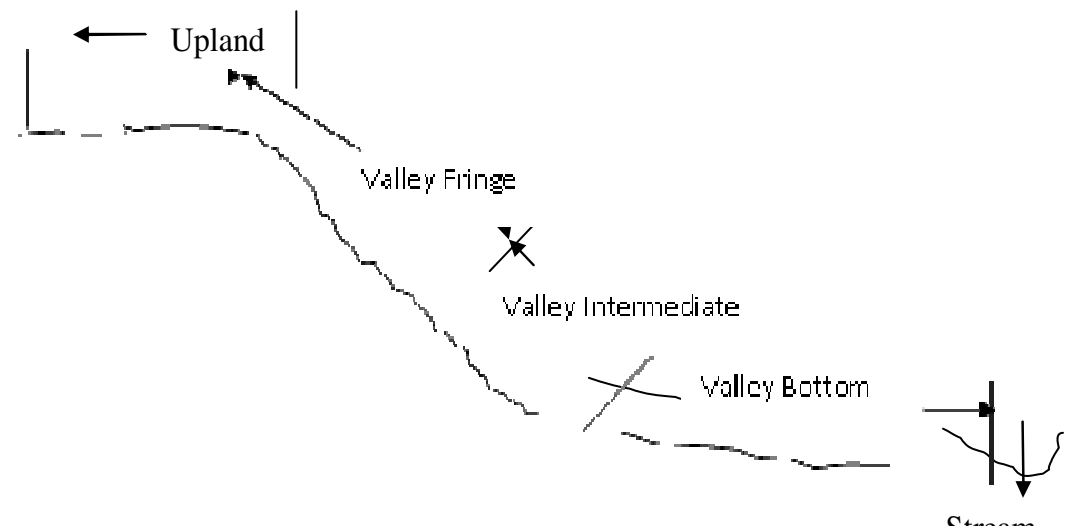

Figure 1. Topographic positions of inland valleys used as test sites.

Table 1. Tuber and vegetative characteristics of cassava cultivars used in the trial.

\begin{tabular}{lcccc}
\hline \multirow{2}{*}{ Parameter } & \multicolumn{4}{c}{ Characteristics } \\
\cline { 2 - 5 } Tuber characteristics & TMS 4(2)1425 & TMS 91/02324 & TMS 91/02327 & Isunikankiyan \\
Fresh yield (t/ha) & $12.98-84.42$ & $14.84-28.16$ & $13.00-24.58$ & $2.00-10.00$ \\
Dry matter (\%) & $28.46-39.67$ & $21.37-37.40$ & $27.34-36.75$ & $30.46-40.05$ \\
CNP (ppm) & $2.69-12.84$ & $6.81-21.75$ & $4.08-25.83$ & $2.58-6.88$ \\
Starch (\%) & $61.64-73.97$ & $61.64-75.15$ & $24.58-73.54$ & $27.90-60.08$ \\
Protein (\%) & $1.60-4.87$ & $1.57-7.20$ & $1.23-5.50$ & $1.20-4.89$ \\
Outer root skin colour & Cream & Cream & Cream & Pale brown \\
Inner root skin colour & White/cream & White/cream & White/cream & White \\
Root flesh colour & White & White & White & White \\
Root neck length & Short & Short & Short & Medium \\
& & & & \\
Vegetative characteristics & Green purple & Green purple & Green purple & Green \\
\hline Unexpanded leaf colour & Green purple & Green purple & Green purple & Green \\
1st fully expanded leaf colour & Moderate & Moderate & Moderate & Low \\
Pubescence of young leaf & Elliptic & Lanceolate & Lanceolate & Lanceolate \\
Central leaf lobe shape & Light green & Dark green & Green purple & Red \\
Petiole colour & Silver green & Dark brown & Dark brown & Grey \\
Stem colour & Zigzag branching & Straight & Straight & Straight \\
Growth habit of stem & & & & \\
\hline
\end{tabular}

of leaf ageing, drought or excess moisture condition, low night temperatures and harmattan winds were visually rated using stay green score (SGS) on a scale of 1 to 9 ; where 1 = plant with a full canopy, retaining most formed leaves and $9=$ complete defoliation with a candlestick appearance of the stem (Ekanayake, 1996; Lenis et al., 2005).

\section{Harvesting and tuber yield determination}

The 2001 and 2002 trials were harvested on 15 August 2001 and 23 July 2002 at Ibadan and on 13 September 2001 and 28 July 2002 at Alabata, respectively. All the plants in each plot were harvested. Storage root biomass weights were recorded and subsamples of fresh materials $(250 \mathrm{~g})$ were dried in a ventilated oven at $70^{\circ} \mathrm{C}$ for $48 \mathrm{~h}$ to determine dry-matter content. Dry tuber yield was expressed as tons $\mathrm{ha}^{-1}$.

\section{Statistical analyses}

The data were analysed using mixed model procedure (PROC MIXED) of the statistical analysis system for Microsoft Windows (SAS Institute, 1991). Row and column were taken as random effects and cultivar, toposequence position, site and year as fixed effects. Significant differences between treatments were compared 
(a) (February - September 2001)

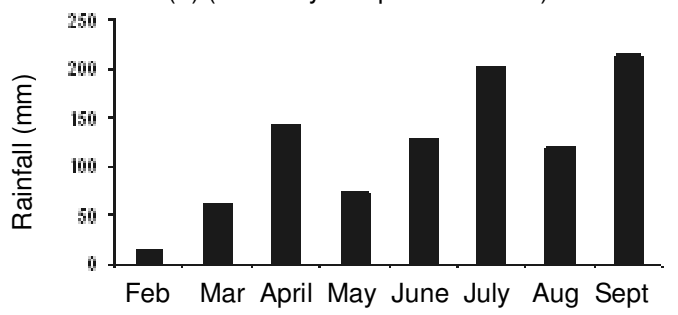

(c) Ibadan (February - September 2001)

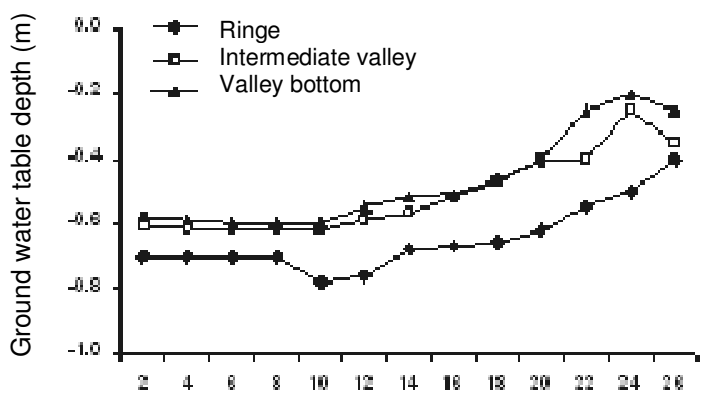

(b) (December 2001 - July 2002)

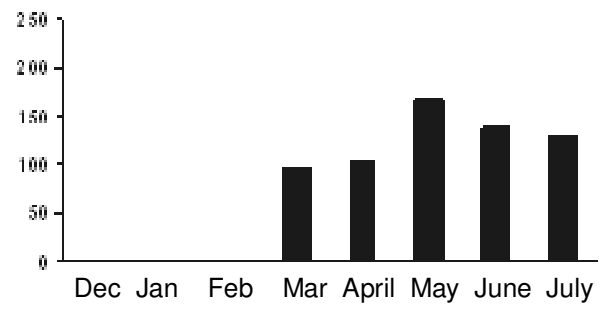

(d) Ibadan (December 2001 - July 2002)

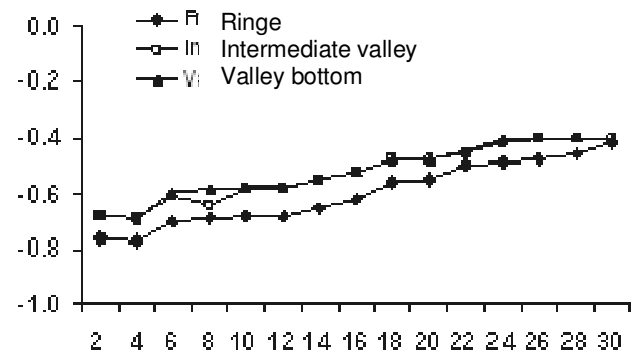

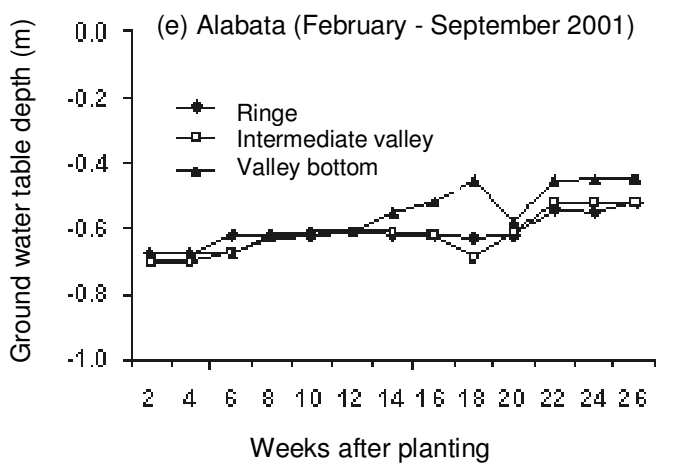

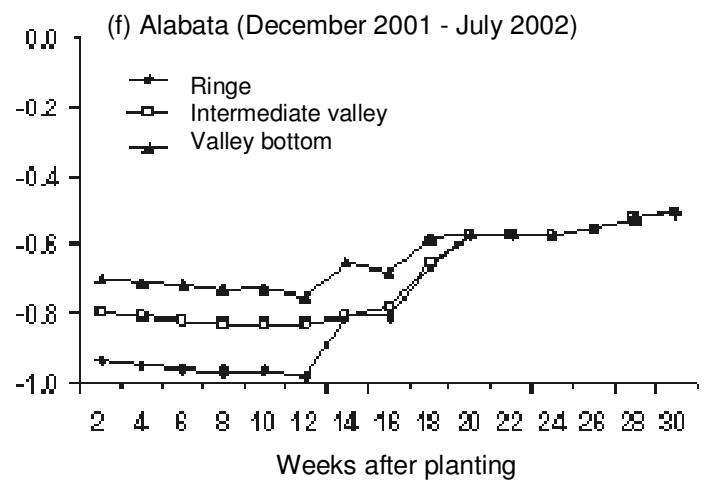

Figure 2. Variations in rainfall (at lbadan) and groundwater table depth during 2001 and 2002 cropping seasons in inland valley at Ibadan and Alabata, Nigeria.

using standard error of the mean. Relationships between canopy parameters and root yield, water table depth and weather variables were explored using conventional correlation approach.

\section{RESULTS}

\section{Groundwater table depth at both sites}

At both sites in both years, water table depth decreased as rainfall increased. The water table was deeper at both sites in 2002 with lower rainfall than in 2001. It was also deeper in the fringe than the other positions at both sites and years. The shallowest water table depth attained at Ibadan ranged from 0.15 to $0.40 \mathrm{~m}$ in 2001 and from 0.35 to $0.45 \mathrm{~m}$ in 2002, while at Alabata it ranged from 0.45 to
$0.50 \mathrm{~m}$ in 2001 and from 0.51 to $0.58 \mathrm{~m}$ in 2002 below the $0.6 \mathrm{~m}$-high mound surface (Figure 2).

\section{Dry tuberous root yield}

Improved cultivars had significantly higher root yields than the landrace across toposequence positions at both sites in both years. However, TMS 91/02324 and TMS $91 / 02327$ had similar but significantly higher yields than TMS 4(2)1425. Across cultivars in 2001, the highest yield was obtained in valley bottom and the lowest in valley fringe at Alabata, while in 2002 at Alabata and in both years at Ibadan the highest yield was produced in the fringe and the lowest in valley bottom. This led to signi- 
Table 2. Influence of cassava cultivars and toposequence positions on dry tuber yield ( $\mathrm{t} \mathrm{ha}{ }^{-1}$ ) and number of leaves plant ${ }^{-1}$ at two inland valley locations in 2001 and 2002 (Nigeria).

\begin{tabular}{|c|c|c|c|c|c|c|c|c|c|}
\hline \multirow{3}{*}{$\begin{array}{l}\text { Location } \\
\text { (Loc) }\end{array}$} & \multirow{3}{*}{ Cultivar } & \multicolumn{4}{|c|}{2001} & \multicolumn{4}{|c|}{2002} \\
\hline & & \multicolumn{3}{|c|}{ Toposequence (Topo) } & \multicolumn{5}{|c|}{ Toposequence (Topo) } \\
\hline & & Fringe & $\begin{array}{c}\text { Inter- } \\
\text { mediate }\end{array}$ & Bottom & $\begin{array}{c}\text { Cultivar } \\
\text { Mean }\end{array}$ & Fringe & $\begin{array}{c}\text { Inter- } \\
\text { mediate }\end{array}$ & Bottom & $\begin{array}{c}\text { Cultivar } \\
\text { mean }\end{array}$ \\
\hline & & \multicolumn{8}{|c|}{ (a) Dry tuberous root yield $\left(\mathrm{t} \mathrm{ha}^{-1}\right)$} \\
\hline \multirow[t]{8}{*}{ Alabata } & TMS4(2)1425 & 5.04 & 6.16 & 16.94 & 9.38 & 3.28 & 2.24 & 3.01 & 2.84 \\
\hline & TMS91/02324 & 4.68 & 4.71 & 17.24 & 8.88 & 4.12 & 4.01 & 4.66 & 4.26 \\
\hline & TMS91/02327 & 5.31 & 5.50 & 17.21 & 9.34 & 5.15 & 3.60 & 3.12 & 3.96 \\
\hline & Isunikankiyan & 4.17 & 4.98 & 15.23 & 8.13 & 1.86 & 1.97 & 0.95 & 1.59 \\
\hline & s.e \pm & 0.64 & 0.64 & 0.64 & 0.32 & 0.64 & 0.64 & 0.64 & 0.32 \\
\hline & Topo mean (s.e \pm 0.32$)$ & 4.80 & 5.34 & 16.66 & - & 3.60 & 2.96 & 2.94 & - \\
\hline & Year mean (s.e \pm 0.17$)$ & 8.93 & - & - & - & 3.17 & - & - & - \\
\hline & Loc mean (s.e \pm 0.13$)$ & 6.05 & - & - & - & - & - & - & - \\
\hline \multirow[t]{9}{*}{ Ibadan } & TMS4(2)1425 & 4.56 & 4.22 & 3.23 & 4.00 & 3.18 & 2.30 & 1.67 & 2.38 \\
\hline & TMS91/02324 & 7.77 & 4.13 & 5.04 & 5.65 & 5.48 & 2.52 & 2.62 & 3.54 \\
\hline & TMS91/02327 & 6.12 & 4.51 & 4.41 & 5.01 & 5.14 & 2.38 & 2.04 & 3.19 \\
\hline & Isunikankiyan & 3.83 & 2.99 & 3.15 & 3.32 & 2.58 & 1.35 & 1.56 & 1.83 \\
\hline & s.e \pm & 0.64 & 0.64 & 0.64 & 0.32 & 0.64 & 0.64 & 0.64 & 0.32 \\
\hline & Topo mean (s.e \pm 0.32$)$ & 5.50 & 3.96 & 3.96 & - & 4.10 & 2.14 & 1.97 & - \\
\hline & Year mean (s.e \pm 0.17$)$ & 4.47 & - & - & - & 2.74 & - & - & - \\
\hline & Loc mean (s.e \pm 0.13$)$ & 3.61 & - & - & - & - & - & - & - \\
\hline & & \multicolumn{8}{|c|}{ (b) Number of leaves per plant } \\
\hline \multirow[t]{8}{*}{ Alabata } & TMS4(2)1425 & 131.4 & 100.7 & 116.3 & 116.1 & 76.1 & 63.7 & 53.7 & 64.5 \\
\hline & TMS91/02324 & 82.2 & 84.6 & 86.8 & 84.5 & 72.8 & 46.7 & 56.6 & 58.7 \\
\hline & TMS91/02327 & 100.2 & 81.6 & 68.5 & 83.5 & 70.6 & 57.6 & 42.4 & 56.9 \\
\hline & Isunikankiyan & 107.5 & 81.9 & 67.8 & 85.7 & 49.9 & 38.6 & 36.0 & 41.5 \\
\hline & s.e \pm & 8.6 & 8.6 & 8.6 & 3.8 & 8.6 & 8.6 & 8.6 & 3.8 \\
\hline & Topo mean $(s . e \pm 2.1)$ & 105.3 & 87.2 & 84.9 & - & 67.4 & 51.7 & 47.2 & - \\
\hline & Year mean $($ s.e \pm 2.6$)$ & 92.5 & - & - & - & 55.4 & - & - & - \\
\hline & Loc mean (s.e \pm 2.4$)$ & 74.0 & - & - & - & - & - & - & - \\
\hline \multirow[t]{8}{*}{ Ibadan } & TMS4(2)1425 & 135.7 & 117.7 & 96.8 & 116.7 & 107.3 & 55.5 & 53.6 & 72.1 \\
\hline & TMS91/02324 & 117.1 & 64.0 & 61.2 & 80.8 & 82.5 & 51.1 & 51.4 & 61.7 \\
\hline & TMS91/02327 & 101.2 & 65.7 & 57.6 & 74.8 & 94.9 & 46.9 & 56.6 & 66.1 \\
\hline & Isunikankiyan & 72.9 & 52.3 & 56.9 & 60.7 & 67.3 & 45.8 & 46.1 & 53.1 \\
\hline & s.e \pm & 8.6 & 8.6 & 8.6 & 3.8 & 8.6 & 8.6 & 8.6 & 3.8 \\
\hline & Topo mean (s.e \pm 2.1 ) & 106.7 & 74.9 & 68.1 & - & 88.0 & 49.8 & 51.9 & - \\
\hline & Year mean $($ s.e \pm 2.6$)$ & 83.2 & - & - & - & 63.2 & - & - & - \\
\hline & Loc mean (s.e \pm 2.4$)$ & 73.2 & - & - & - & - & - & - & - \\
\hline
\end{tabular}

s.e. $=$ standard error of means.

ficant toposequence position $\times$ site, toposequence position $\times$ year, site $\times$ year and toposequence position $\times$ site $\times$ year interactions. Root yield was about $55 \%$ higher in 2001 than 2002 and 46\% higher at Alabata than Ibadan (Table 2a).

\section{Number of leaves}

On average, the improved cultivars had higher number of leaves than the landrace, with TMS 4(2)1425 producing significantly more leaves than the other improved cultivars in all toposequence positions at both sites in both years. Plants in the fringe recorded significantly higher number of leaves than the other positions at both sites in both years. In all cases plants in valley bottom produced the lowest number of leaves. Leaf number was about 33\% higher in 2001 than 2002. Site $\times$ year interaction was significant because leaf number was 
higher at Alabata than Ibadan in 2001, but in 2002, it was higher at Ibadan than Alabata (Table 2b).

\section{Rate of leaf formation}

The landrace, TMS 4(2)1425 and TMS 91/02324 had similar rate of leaf formation, but the landrace and TMS 4(2)1425 formed leaves at faster rate than TMS 91/02327 across toposequence positions, sites and years. Rate of leaf formation was higher at Ibadan (27\%) than Alabata and was also higher in 2001 than in 2002, but this was more pronounced at Alabata (83\%) than at Ibadan (24\%). Rate of leaf formation was affected by toposequence position $\times$ site interaction as it was lowest in valley fringe and highest in valley bottom at Alabata, while at Ibadan it was highest in the fringe and lowest in valley bottom. Toposequence position $\times$ year interaction was significant due to the fact that rate of leaf formation in 2001 was highest in valley bottom and lowest in valley fringe, but the reverse was the case in 2002 (Table 3a).

\section{Leaf area index}

TMS 4(2)1425 had the highest leaf area index (LAl), followed by TMS 91/02324 and TMS 91/02327, while Isunikankiyan had the lowest LAl across toposequence positions at both locations in both years. Plants in valley fringe produced higher LAI than those in other positions, with plants in valley intermediate and bottom registering similar LAl at both sites and in both years. LAI was about $60 \%$ higher in 2001 than in 2002 and was $41 \%$ higher at Alabata than Ibadan. Cultivar $x$ site and cultivar $x$ year interactions were significant because at Alabata, TMS 91/02327 had lower LAI than the landrace but the reverse was recorded at Ibadan. Similarly in 2001, TMS 4(2)1425 had larger LAl than TMS 91/02324 but in 2002 the reverse was the case (Table $3 b$ ).

\section{Canopy area}

Generally, in each toposequence position at both sites in both years, the three improved cultivars had significantly larger canopy area than the landrace cultivar. Plants in valley fringe had larger canopy area than the other positions, with the other two positions producing similar canopy area at both sites in both years. Canopy area was about 40\% higher in 2001 than in 2002 and about 34\% larger at Alabata than Ibadan. The interaction effects on canopy area were not directional since cultivars changed their rankings only slightly over toposequence positions, sites and years (Table 4a).

\section{Stay-green score}

Stay-green score (SGS) of the landrace was significantly higher than the other cultivars, with the improved cultivars having similar SGS across toposequence positions at both sites in both years. The lower the SGS the better the stay green ability, indicating that SGS of the improved cultivars was better than that of the landrace. Plants in valley fringe had better SGS than those in valley bottom. Also, SGS in 2001 was better than in 2002 at Alabata, but the reverse was noted at Ibadan. Mean SGS at Alabata was better than that at Ibadan. Toposequence position $\times$ site $\times$ year interaction was noted. At Alabata, in both years, the fringe had the lowest, while valley bottom had the highest SGS. At Ibadan, in 2001, the fringe had the lowest and valley bottom had the highest, but in 2002, valley bottom had the lowest and the fringe had the highest score (Table 4b).

\section{Associations of canopy parameters with yield, water table depth and weather variables}

Number and rate of leaf formation, LAI and canopy area correlated positively with yield at both sites. SGS related negatively with yield at Alabata. At Ibadan, water table depth had negative relationship with leaf number, rate of leaf formation, LAI and canopy area, but positive association with SGS, whereas at Alabata, SGS correlated negatively with water table depth. Leaf number, rate of leaf formation, LAI and canopy area related positively with rainfall, minimum temperature and relative humidity, but negatively with evaporation, solar radiation and maximum temperature (Table 5).

\section{DISCUSSION}

\section{Number of leaves per plant}

Plants obtain their energy and structural materials by photosynthesis and the main photosynthetic organ is the leaf (Jarvis and Morison, 1982; Lenis et al., 2005; Lebot, 2009). This indicates that the higher the number of leaves the higher the photosynthate produced. Leaf number correlated positively with root yield at both sites. Thus, the high tuber yields in 2001 and also of the improved cultivars were partly due to the production of higher number of leaves. The results agreed with Adeniji et al. (2011) who reported that cassava leaves are important determinant of tuber yield. However, TMS 4(2)1425 with the highest leaf number yielded lower than the other improved cultivars. TMS 4(2)1425 branches or forks early, about two months after planting and continues branching until harvest. Due to this branching habit, it produced higher number of leaves than the other cultivars. Shoot apices and storage roots compete for carbohydrate in cassava (Tan and Cock, 1979a). The high number of branches most likely increased competition for available carbohydrate, which may have reduced root yield in TMS 4(2)1425 as compared to the other improved cultivars.

Plants in the fringe with deep water table produced the 
Table 3. Influence of cassava cultivars and toposequence positions on rate of leaf formation (day ${ }^{-1}$ plant $^{-1}$ ) and leaf area index (LAI) at two inland valley locations in 2001 and 2002 (Nigeria).

\begin{tabular}{|c|c|c|c|c|c|c|c|c|c|}
\hline \multirow{3}{*}{$\begin{array}{l}\text { Location } \\
\text { (Loc) }\end{array}$} & \multirow{3}{*}{ Cultivar } & \multicolumn{4}{|c|}{2001} & \multicolumn{4}{|c|}{2002} \\
\hline & & \multicolumn{3}{|c|}{ Toposequence (Topo) } & \multicolumn{5}{|c|}{ Toposequence (Topo) } \\
\hline & & Fringe & $\begin{array}{c}\text { Inter- } \\
\text { mediate }\end{array}$ & Bottom & $\begin{array}{c}\text { Cultivar } \\
\text { Mean }\end{array}$ & Fringe & $\begin{array}{c}\text { Inter- } \\
\text { mediate }\end{array}$ & Bottom & $\begin{array}{c}\text { Cultivar } \\
\text { Mean }\end{array}$ \\
\hline & & \multicolumn{8}{|c|}{ (a) Rate of leaf formation (day $^{-1}$ plant $^{-1}$ ) } \\
\hline \multirow{8}{*}{ Alabata } & TMS4(2)1425 & 1.6 & 1.7 & 1.9 & 1.7 & 0.2 & 0.4 & 0.3 & 0.3 \\
\hline & TMS91/02324 & 1.0 & 1.7 & 2.1 & 1.6 & 0.3 & 0.3 & 0.4 & 0.3 \\
\hline & TMS91/02327 & 1.1 & 1.5 & 1.7 & 1.4 & 0.2 & 0.4 & 0.3 & 0.3 \\
\hline & Isunikankiyan & 1.5 & 2.0 & 2.3 & 1.9 & 0.2 & 0.3 & 0.2 & 0.2 \\
\hline & s.e \pm & 0.3 & 0.3 & 0.3 & 0.1 & 0.3 & 0.3 & 0.3 & 0.1 \\
\hline & Topo mean (s.e \pm 0.07 ) & 1.3 & 1.7 & 2.0 & - & 0.2 & 0.4 & 0.3 & - \\
\hline & Year mean $(s . e \pm 0.05)$ & 1.7 & - & - & - & 0.3 & - & - & - \\
\hline & Loc mean (s.e \pm 0.04$)$ & 1.0 & - & - & - & - & - & - & - \\
\hline \multirow[t]{9}{*}{ Ibadan } & TMS4(2)1425 & 2.2 & 1.7 & 2.1 & 2.0 & 1.5 & 0.9 & 1.1 & 1.2 \\
\hline & TMS91/02324 & 1.7 & 1.0 & 1.7 & 1.5 & 1.6 & 1.2 & 1.4 & 1.4 \\
\hline & TMS91/02327 & 1.4 & 1.7 & 1.2 & 1.4 & 1.8 & 1.3 & 1.3 & 1.5 \\
\hline & Isunikankiyan & 2.1 & 2.0 & 1.6 & 1.9 & 1.4 & 1.3 & 1.4 & 1.4 \\
\hline & s.e \pm & 0.3 & 0.3 & 0.3 & 0.1 & 0.3 & 0.3 & 0.3 & 0.1 \\
\hline & Topo mean (s.e \pm 0.07$)$ & 1.9 & 1.6 & 1.7 & - & 1.6 & 1.2 & 1.3 & - \\
\hline & Year mean (s.e \pm 0.05$)$ & 1.7 & - & - & - & 1.4 & - & - & - \\
\hline & Loc mean (s.e \pm 0.04$)$ & 1.6 & - & - & - & - & - & - & \\
\hline & & \multicolumn{8}{|c|}{ (b) Leaf area index (LAI) } \\
\hline \multirow[t]{8}{*}{ Alabata } & TMS4(2)1425 & 6.6 & 5.0 & 5.4 & 5.7 & 3.1 & 2.6 & 1.8 & 2.5 \\
\hline & TMS91/02324 & 4.6 & 4.7 & 4.9 & 4.7 & 3.2 & 2.0 & 2.3 & 2.5 \\
\hline & TMS91/02327 & 4.2 & 3.3 & 3.5 & 3.7 & 2.4 & 1.7 & 1.4 & 1.8 \\
\hline & Isunikankiyan & 5.1 & 4.5 & 3.5 & 4.4 & 2.1 & 1.8 & 1.3 & 1.7 \\
\hline & s.e \pm & 0.5 & 0.5 & 0.5 & 0.2 & 0.5 & 0.5 & 0.5 & 0.2 \\
\hline & Topo mean (s.e \pm 0.1$)$ & 5.1 & 4.4 & 4.4 & - & 2.7 & 2.0 & 1.7 & - \\
\hline & Year mean (s.e \pm 0.1$)$ & 4.6 & - & - & - & 2.1 & - & - & - \\
\hline & Loc mean (s.e \pm 0.1$)$ & 3.4 & - & - & - & - & - & - & - \\
\hline \multirow[t]{8}{*}{ Ibadan } & TMS4(2)1425 & 6.9 & 3.9 & 2.7 & 4.5 & 3.0 & 0.9 & 1.0 & 1.6 \\
\hline & TMS91/02324 & 6.7 & 1.3 & 1.7 & 3.2 & 3.2 & 0.8 & 1.1 & 1.7 \\
\hline & TMS91/02327 & 5.8 & 1.4 & 1.5 & 2.9 & 3.3 & 0.5 & 1.2 & 1.7 \\
\hline & Isunikankiyan & 3.0 & 1.7 & 1.6 & 2.1 & 1.7 & 1.0 & 0.7 & 1.1 \\
\hline & s.e \pm & 0.5 & 0.5 & 0.5 & 0.2 & 0.5 & 0.5 & 0.5 & 0.2 \\
\hline & Topo mean (s.e \pm 0.1$)$ & 5.6 & 2.1 & 1.9 & - & 2.8 & 0.8 & 1.0 & - \\
\hline & Year mean (s.e \pm 0.1$)$ & 3.2 & - & - & - & 1.5 & - & - & - \\
\hline & Loc mean (s.e \pm 0.1$)$ & 2.4 & - & - & - & - & - & - & - \\
\hline
\end{tabular}

s.e $=$ standard error of means

highest leaf number, while valley bottom with shallow water table had the lowest number. These results corroborate those of Lahai et al. (1999) and Jalloh and Palada (1989) who have noted better performance of cassava in valley fringe than valley bottom. Also, at shallow water table site at Ibadan, water table depth correlated negatively with leaf number, but the relationship was not significant at Alabata with deep water table. This indicated that shallow water table depth reduced root yield partly by decreasing leaf number. Lahai et al. (1999) and Mohamoud (1994) reported similar results. In 2001, with relatively well distributed 
Table 4. Influence of cassava cultivars and toposequence positions on canopy area $\left(\mathrm{m}^{2}\right)$ and stay-green score (SGS) at two inland valley locations in 200 and 2002 (Nigeria).

\begin{tabular}{|c|c|c|c|c|c|c|c|c|c|}
\hline \multirow{3}{*}{$\begin{array}{l}\text { Location } \\
\text { (Loc) }\end{array}$} & \multirow{3}{*}{ Cultivar } & \multicolumn{4}{|c|}{2001} & \multicolumn{4}{|c|}{2002} \\
\hline & & \multicolumn{3}{|c|}{ Toposequence (Topo) } & \multicolumn{5}{|c|}{ Toposequence (Topo) } \\
\hline & & Fringe & $\begin{array}{c}\text { Inter- } \\
\text { mediate }\end{array}$ & Bottom & $\begin{array}{c}\text { Cultivar } \\
\text { Mean }\end{array}$ & Fringe & $\begin{array}{c}\text { Inter- } \\
\text { mediate }\end{array}$ & Bottom & $\begin{array}{c}\text { Cultivar } \\
\text { Mean }\end{array}$ \\
\hline & & \multicolumn{8}{|c|}{ (a) Canopy area $\left(\mathrm{m}^{2}\right)$} \\
\hline \multirow[t]{8}{*}{ Alabata } & TMS4(2)1425 & 2.2 & 1.6 & 2.3 & 2.0 & 1.9 & 1.0 & 1.0 & 1.3 \\
\hline & TMS91/02324 & 1.6 & 1.2 & 1.4 & 1.4 & 0.9 & 0.7 & 0.8 & 0.8 \\
\hline & TMS91/02327 & 1.3 & 1.1 & 1.2 & 1.2 & 1.0 & 0.7 & 0.5 & 0.7 \\
\hline & Isunikankiyan & 1.4 & 1.0 & 1.0 & 1.1 & 0.8 & 0.7 & 0.6 & 0.7 \\
\hline & s.e \pm & 0.09 & 0.09 & 0.09 & 0.06 & 0.09 & 0.09 & 0.09 & 0.06 \\
\hline & Topo mean (s.e \pm 0.03$)$ & 1.6 & 1.2 & 1.5 & - & 1.2 & 0.8 & 0.7 & - \\
\hline & Year mean (s.e \pm 0.04$)$ & 1.4 & - & - & - & 0.9 & - & - & - \\
\hline & Loc mean (s.e \pm 0.03$)$ & 1.2 & - & - & - & - & - & - & - \\
\hline \multirow[t]{9}{*}{ Ibadan } & TMS4(2)1425 & 1.5 & 1.2 & 1.2 & 1.3 & 1.0 & 0.4 & 0.5 & 0.6 \\
\hline & TMS91/02324 & 1.5 & 0.7 & 0.7 & 1.0 & 0.8 & 0.5 & 0.6 & 0.6 \\
\hline & TMS91/02327 & 1.3 & 0.6 & 0.7 & 0.9 & 0.9 & 0.4 & 0.6 & 0.6 \\
\hline & Isunikankiyan & 1.0 & 0.6 & 0.6 & 0.7 & 0.7 & 0.5 & 0.5 & 0.6 \\
\hline & s.e \pm & 0.09 & 0.09 & 0.09 & 0.06 & 0.09 & 0.09 & 0.09 & 0.06 \\
\hline & Topo mean (s.e \pm 0.03$)$ & 1.3 & 0.8 & 0.8 & - & 0.9 & 0.5 & 0.6 & - \\
\hline & Year mean (s.e \pm 0.04$)$ & 1.0 & - & - & - & 0.6 & - & - & - \\
\hline & Loc mean (s.e \pm 0.03$)$ & 0.8 & - & - & - & - & - & - & - \\
\hline & & \multicolumn{8}{|c|}{ (b) Stay-green score (SGS) } \\
\hline \multirow[t]{8}{*}{ Alabata } & TMS4(2)1425 & 2.1 & 2.1 & 2.4 & 2.2 & 3.0 & 3.0 & 3.3 & 3.1 \\
\hline & TMS91/02324 & 2.0 & 2.0 & 2.2 & 2.1 & 2.5 & 2.2 & 3.5 & 2.7 \\
\hline & TMS91/02327 & 2.0 & 2.0 & 2.1 & 2.0 & 2.5 & 2.2 & 4.1 & 2.9 \\
\hline & Isunikankiyan & 2.4 & 2.4 & 2.7 & 2.5 & 3.2 & 3.0 & 4.0 & 3.4 \\
\hline & s.e \pm & 0.3 & 0.3 & 0.3 & 0.2 & 0.3 & 0.3 & 0.3 & 0.2 \\
\hline & Topo mean (s.e \pm 0.15$)$ & 2.1 & 2.1 & 2.4 & - & 2.8 & 2.6 & 3.7 & - \\
\hline & Year mean (s.e \pm 0.08$)$ & 2.2 & - & - & - & 3.0 & - & - & - \\
\hline & Loc mean (s.e \pm 0.06$)$ & 2.6 & - & - & - & - & - & - & - \\
\hline \multirow[t]{8}{*}{ Ibadan } & TMS4(2)1425 & 3.0 & 3.3 & 3.9 & 3.4 & 3.0 & 2.2 & 2.8 & 2.7 \\
\hline & TMS91/02324 & 3.0 & 3.5 & 3.6 & 3.4 & 3.3 & 2.8 & 2.5 & 2.9 \\
\hline & TMS91/02327 & 2.8 & 3.5 & 3.8 & 3.4 & 3.0 & 2.7 & 2.8 & 2.8 \\
\hline & Isunikankiyan & 3.7 & 4.5 & 4.6 & 4.3 & 3.5 & 3.0 & 3.0 & 3.2 \\
\hline & s.e \pm & 0.3 & 0.3 & 0.3 & 0.2 & 0.3 & 0.3 & 0.3 & 0.2 \\
\hline & Topo mean (s.e \pm 0.15$)$ & 3.1 & 3.7 & 4.0 & - & 3.2 & 2.7 & 2.8 & - \\
\hline & Year mean (s.e \pm 0.08$)$ & 3.6 & - & - & - & 2.9 & - & - & - \\
\hline & Loc mean (s.e \pm 0.06$)$ & 3.3 & - & - & - & - & - & - & - \\
\hline
\end{tabular}

s.e = standard error of means; SGS rated on a scale of 1 to 9 where: 1 = a normal plant with a full canopy, retaining most formed leaves which are green, turgid and photosynthetically active; $3=30 \%$ of the leaves have dropped; less than $50 \%$ of the remaining older leaves are droopy, partially wilted or dry; young leaves have reduced greenness; $5=50 \%$ reduction of the leaf number as compared to full canopy; most of the older leaves are droopy, wilted and dry; most of the young leaves have reduced greenness; $7=80 \%$ reduction of the leaf number as compared to full canopy; more than $75 \%$ of the remaining are wilted or brown; young leaves have reduced greenness; $9=$ complete defoliation of the stems, with a candlestick appearance and some dieback of the stems evident.

rainfall and moderate temperature, evaporation and solar radiation and high relative humidity, leaf number was higher than in 2002 with low rainfall and relative humidity, but high temperature, evaporation and solar radiation. 


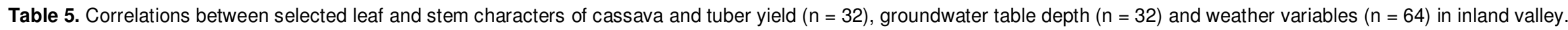

\begin{tabular}{|c|c|c|c|c|c|c|c|c|c|c|c|c|c|c|c|c|c|c|c|c|}
\hline \multirow{3}{*}{ Canopy parameter } & \multicolumn{4}{|c|}{ Tuberous root yield $\left(\mathrm{t} \mathrm{ha}^{-1}\right)$} & \multicolumn{4}{|c|}{$\begin{array}{l}\text { Groundwater table depth } \\
(\mathrm{m})\end{array}$} & \multicolumn{12}{|c|}{ Weather variable } \\
\hline & \multicolumn{2}{|c|}{ Alabata } & \multicolumn{2}{|c|}{ Ibadan } & \multicolumn{2}{|c|}{ Alabata } & \multicolumn{2}{|c|}{ Ibadan } & \multicolumn{2}{|c|}{$\begin{array}{l}\text { Rainfall } \\
(\mathrm{mm})\end{array}$} & \multicolumn{2}{|c|}{$\begin{array}{l}\text { Evaporation } \\
\text { rate }(\mathrm{mm})\end{array}$} & \multicolumn{2}{|c|}{$\begin{array}{c}\text { Solar } \\
\text { radiation } \\
\text { (MJ/m/day) }\end{array}$} & \multicolumn{2}{|c|}{$\begin{array}{c}\text { Minimum } \\
\text { temperature } \\
\left({ }^{\circ} \mathrm{C}\right)\end{array}$} & \multicolumn{2}{|c|}{$\begin{array}{l}\text { Maximum } \\
\text { temperature } \\
\left({ }^{\circ} \mathrm{C}\right)\end{array}$} & \multicolumn{2}{|c|}{$\begin{array}{c}\text { Relative } \\
\text { humidity } \\
(\%)\end{array}$} \\
\hline & $r$ & $p$ & $r$ & $\mathbf{P}$ & $r$ & $\mathbf{P}$ & $r$ & $\mathbf{P}$ & $r$ & $p$ & $r$ & $p$ & $\mathbf{R}$ & $p$ & $r$ & $\mathbf{p}$ & $r$ & $p$ & $r$ & $p$ \\
\hline$\overline{\text { Numl }}$ & 0.44 & 0.011 & 0.60 & 0.0002 & 0.27 & 0.1337 & -0.67 & 0.0001 & 0.57 & 0.0001 & -0.57 & 0.0001 & -0.57 & 0.0001 & 0.57 & 0.0001 & -0.57 & 0.0001 & 0.57 & 0.0001 \\
\hline Rate o & 0.79 & 0.0001 & 0.35 & 0.0468 & -0.18 & 0.3303 & -0.50 & 0.0036 & 0.69 & 0.0001 & -0.69 & 0.0001 & -0.69 & 0.0001 & 0.69 & 0.0001 & -0.69 & 0.0001 & 0.69 & 0.0001 \\
\hline Leaf area index (LAI) & 0.54 & 0.0015 & 0.72 & 0.0001 & 0.21 & 0.2587 & -0.64 & 0.0001 & 0.60 & 0.0001 & -0.60 & 0.0001 & -0.60 & 0.0001 & 0.60 & 0.0001 & -0.60 & 0.0001 & 0.60 & 0.0001 \\
\hline Canopy area & 0.48 & 0.0055 & 0.69 & 0.0001 & 0.18 & 0.3359 & -0.63 & 0.0001 & 0.51 & 0.0001 & -0.51 & 0.0001 & -0.51 & 0.0001 & 0.50 & 0.0001 & -0.51 & 0.0001 & 0.51 & 0.0001 \\
\hline Stay green score (SGS) & -0.46 & 0.0076 & -0.21 & 0.2415 & -0.47 & 0.0061 & 0.50 & 0.0036 & -0.04 & 0.7406 & 0.04 & 0.7406 & 0.04 & 0.7406 & -0.04 & 0.7406 & 0.04 & 0.7406 & -0.04 & 0.7406 \\
\hline
\end{tabular}

This was supported by the positively with root yield at both sites. Similar results were obtained in the upland (El-Sharkawy et al., 1992; Indira, 1996). Photosynthetic rate of cassava leaves decreases markedly with leaf age (Aslam et al., 1977; Lebot, 2009). Also, new leaves formed increase leaf number or replace fallen ones. Increase in the number coupled with high photosynthetic rate of new leaves likely contributed to high root yield. Rate of leaf formation was related to branch number and rate of leaf retention. Irikura et al. (1979) reported that early branching increases leaf formation rate, while Okogbenin et al. (1999) noted that cultivars with high branching characteristics produced more leaves than non-branching ones and that planting methods that favoured leaf production profusely shed more leaves than planting methods with less leaf formation. Results of this study are consistent with these findings in that TMS 4(2)1425, a branching cultivar, TMS 91/02324 with high stem number and the landrace with low leaf number had higher leaf formation rate than TMS 91/02327 with high rate of leaf retention.
Correlation results with weather variables for rate of leaf formation were similar to those for leaf number, indicating that increase in rate of leaf formation increases leaf number. Similarly, water table depth correlated negatively with both number and rate of leaf production at the shallow water table site at Ibadan, but in correlations at Alabata, the deep water table site were not significant, indicating that shallow water table partly reduced root yield by reducing leaf production. Rate of leaf formation at Alabata was lower in valley fringe than valley bottom, whereas at Ibadan it was higher in the fringe than valley bottom. Water table appeared to be deeper in the fringe, likely causing drought stress at Alabata, while the valley bottom at Ibadan had shallower water table and both situations reduced leaf production. With high rainfall in 2001, both number and rate of leaf formation were higher at Alabata than Ibadan, which was partly due to shallower water table depth at lbadan than Alabata. With low rainfall, water table depth increased markedly and drought stress likely contributed to the drastic reduction in number and rate of leaf production at Alabata in 2002. At Ibadan, with also deeper water table in 2002 than in 2001, but at the same time shallower than at Alabata, both parameters were higher than at Alabata.

\section{Leaf area index}

High yielding cultivars have high LAI (Lahai et al., 1999; Adejinj et al., 2011). The improved cultivars with high LAl produced high root yield, indicating higher photosynthetic capacity of these cultivars than the landrace. Marked positive correlation existed between LAI and tuber yield, stressing the importance of LAI in yield determination. Lahai et al. (1999) and Lebot (2009) reported similar relationship. However, TMS 4(2)1425 with the highest LAl did not give the highest yield. This suggests that other parameters of canopy function, such as leaf carbon fixation and assimilate partitioning could interact significantly in yield formation. TMS 4(2) 1425 had lower photosynthetic efficiency (Lahai and Ekanayake, 2010) and partitioned lower dry matter into roots, 
but higher dry matter into leaves and stems than the other improved cultivars (Lahai and Ekanayake, 2009), partially explaining the lower yield of TMS 4(2)1425 even though it had the highest LAI. LAl development took about four months to reach maximum values at both sites, parallel with gradual decrease in water table depth, but between 0.58 to $0.65 \mathrm{~m}$ below the mound tops. Then, LAl decreased rapidly, which corresponded to rapid decrease in water table depth to between 0.20 to $0.55 \mathrm{~m}$ below mound tops. Plants in valley fringe had higher LAI than those in other positions and LAI correlated negatively with water table depth at Ibadan. The lowest water table depth at Ibadan was 0.20 and $0.45 \mathrm{~m}$ below mound top in 2001 and 2002, respectively, which was within the range $(0.2$ to $0.4 \mathrm{~m})$ when water table depth is stressful to cassava (Lahai and Ekanayake, 2009). However, the lowest depth at Alabata $(0.50 \mathrm{~m}$ in 2001 and $0.58 \mathrm{~m}$ in 2002 below mound top) was above this range. The high LAI in the fringe as well as at Alabata as compared to other toposequence positions and Ibadan was partly due to deep water table. Similarly, the drastic reduction in LAI at 4 months after planting (MAP) at both sites and years was partially due to decrease in water table depth during this period. Lahai et al. (1999) also noted drastic reduction in LAI after 4 MAP as water table depth decreased in inland valley.

LAl increases with increase in temperature from 20 to $24^{\circ} \mathrm{C}$ due to early branching and increased leaf formation and size, but above $24^{\circ} \mathrm{C}$ branch number and leaf life are reduced (Irikura et al., 1979). The minimum and maximum temperatures were 19.8 and $27.5^{\circ} \mathrm{C}$ in 2001 and 19.1 and $28.4^{\circ} \mathrm{C}$ in 2002 , respectively. The minimum temperatures $\left(19.1\right.$ to $\left.19.8^{\circ} \mathrm{C}\right)$ were within the minimum range that promotes LAl development, while the maximum temperatures $\left(27.1\right.$ to $\left.28.4^{\circ} \mathrm{C}\right)$ were above the maximum that favours high LAl, supporting the positive and negative correlations of LAI with minimum and maximum temperatures, respectively. However, the minimum and maximum temperatures in 2001 were closer to the optimum temperature range that increase LAI than in 2002, which partly contributed to the higher LAI in 2001. Leaf size is greatly reduced when water is withheld (Lenis et al., 2005) which reduces LAl. Thus, the low LAI and tuber yield in 2002 was partly due to reduced leaf size, because of drought during the first three months of growth. However, when LAl was reduced for all cultivars in 2002, TMS 91/02324 and TMS 91/02327 maintained higher LAI at both sites, suggesting that they were relatively less affected by drought than the other cultivars, which likely contributed to their high root yields. Lahai et al. (1999) noted that LAI of clone 87/29 that gave the highest yield was also less affected by changes in environmental conditions in inland valley.

In cassava, leaf area and tuber develop simultaneously, and assimilate produced is partitioned between growth of leaves and tubers (Lebot, 2009). This results in a delicate balance between top and tuber growth for maximum yield, with maximal tuber growth occurring at LAI of 2.5 to 3.5 at which optimum light interception and utilization occur. Low yielding cultivars maintain either sub-optimal (less than 2) or supra-optimal (more than 4) LAl during the major growth period, which reduce light utilization efficiency (Ramanujam, 1985). Our results are in line with these findings in that in 2002 when LAl was less than 2, root yield was drastically reduced as compared to 2001 when LAl was above 2. Also, at Alabata in 2001, TMS 91/02327 with LAl of 3.6 yielded higher than the other cultivars with LAI above 4. However, yield increased when LAI was 3.6 to 5.6 at Alabata in 2001. Generally, cassava intercepts 90 and $99 \%$ incident radiation at LAI 3 and 6, respectively (CIAT, 1980; Lebot, 2009). Cassava is grown in inland valley in the dry season when solar radiation is at its maximum in the tropics, meaning that at high LAI, high radiation was intercepted, which likely translated into high root yield at Alabata in 2001. This suggests that in inland valley LAI of 4 to 6 may not significantly adversely affect yield due to high solar radiation during this period.

\section{Canopy area}

TMS 4(2)1425 had the largest and the landrace the smallest canopy area. In canopy with full ground cover, over $90 \%$ of incident radiation was intercepted by the top $50 \%$, while canopy with partial ground cover intercepted less radiation (Fukai et al., 1984). Canopy area correlated positively with tuber yield, indicating that the high yield of the improved cultivars was partly due to higher light interception with larger canopy area than the landrace.

This agreed with Lebot (2009) who reported that crop canopy is a yield determinant. However, TMS 4(2)1425 with the largest canopy area had lower yield than the other improved cultivars, indicating that large canopy area may reduce yield. The finding was in line with Fukai et al. (1984) who noted that canopy development and root yield are competing components. However, the marked positive correlation between canopy area and yield in the study indicates that the competition was low, likely due to high solar radiation during the growing season in inland valley.

Plants in valley fringe and Alabata had larger canopy area than those in valley bottom and Ibadan. Also canopy area correlated negatively with water table depth at Ibadan, suggesting that the shallow water table depth at Ibadan and generally in valley bottom reduced canopy area. With a more evenly distributed rainfall, moderate temperature and high relative humidity in 2001, canopy area and LAI were higher than in 2002, with drought and high temperature stresses. Therefore, both shallow water table depth and drought stress may reduce canopy area, LAI and consequently yield in inland valley.

\section{Stay green score}

Strategy to maintain high yield during waterlogging or 
drought is to maintain photosynthetically active leaf area duration (LAD). LAD is indirectly monitored as stay-green score (SGS) (Ekanayake et al., 1996; Lenis et al., 2005). SGS was lower for the improved cultivars and in the fringe than the landrace and other positions. The lower the SGS, the higher the LAD, indicating that the improved cultivars and plants in the fringe had higher LAD than the landrace and those in other positions. High yield depends on the maintenance of an optimum LAl for much of the growing season (Ramanujam and Indira, 1983; Lebot, 2009). SGS correlated negatively with tuber yield, indicating that tuber yield increases with LAD.

LAD depends on individual leaf life. Leaf life in upland was found to be higher for high yielding improved cultivars than the low yielding landraces (Okogbenin et al., 1999; Lebot, 2009). This agreed with results of our study in that the improved cultivars with high LAD yielded higher than the landrace with low LAD. LAD is influenced by water table depth in inland valley (Lahai et al., 1999). In the valley fringe where water table was deeper, LAD was higher than in valley bottom with shallow water table. This partly explains the reason for the high root yield in the fringe at Ibadan with the shallow water table.

Similarly, SGS at Alabata with deep water table was generally better than at Ibadan with shallow water table. SGS correlated negatively with water table depth at Alabata, but positively at Ibadan. This indicated that as water table depth decreased, LAD decreased at Ibadan, whereas at Alabata LAD increased. At Ibadan, with shallow water table, decreasing water table depth caused waterlogging, which causes chlorosis and subsequent death of leaves (Mohamoud, 1994), thereby reducing LAD. However, at Alabata, decreasing water table likely improved soil moisture status, which increased LAD. Okogbenin et al (1999) noted on the upland that higher soil moisture at high water table site stimulated leaf production. At Alabata, in 2001 with high rainfall and relatively shallow water table, SGS was low indicating high LAD, whereas in 2002, with low rainfall and deep water table, SGS was higher and LAD lower than in 2001. On the contrary, at lbadan, in 2001 LAD was lower than in 2002, indicating the adverse effect of decrease in water table depth on stay green ability at a shallow water table site. Thus, SGS may be a good indicator of overall performance of cassava in inland valleys.

There were differences between sites, toposequence positions and years for canopy parameters, mainly due to differences in water table depth and weather conditions. Both supra-optimal and sub-optimal canopy parameters reduced tuber yield, but sub-optimal reduced yield more than supra-optimal parameters largely due to high solar radiation during the growing season in inland valleys. High apex and stem and low leaf numbers increased leaf formation rate, while high leaf retention reduced the same. Shallow water table and drought reduced canopy parameters and yield, while well distributed rainfall, high humidity and moderate temperature 19 to $20^{\circ} \mathrm{C}$ improved them. Canopy parameters of low yielding landrace were more susceptible to shallow water table and drought than high yielding TMS 91/02324 and TMS 91/02327. Therefore, cultivars with good maintenance of canopy parameters during mid-season drought and late season excess moisture can increase tuber yield when combined with other yield determinants in inland valley ecology.

\section{ACKNOWLEDGEMENT}

This study was funded by IITA. The senior author is grateful for the research fellowship awarded by IITA to study for a PhD degree at Njala University, Sierra Leone.

\section{REFERENCES}

Adeniji OT, Odo PE, Ibrahim B (2011). Genetic relationships and selection indices for cassava root yield in Adamawa State, Nigeria. Afr. J. Agric. Res. 6:2931-2934.

Ande OT (2011). Soil suitability evaluation and management for cassava production in the derived savanna area of Southwestern Nigeria. International J. Soil Sci. 6:142-149.

Andriesse W, Fresco LO, Van Duivenbooden N, Windmeizer PN (1994). Multi-scale characterization of Inland Valley agro-ecosystems in West Africa. Netherlands J. Agric. Sci. 42:159-179.

Aslam M, Lowe SB, Hunt LA (1977). Effect of leaf age on photosynthesis and transpiration of cassava. Can. J. Bot. 55: 22882295.

Burns A, Gleadow R, Cliff J, Zacarias A, Cavagnoro T (2010). 'Cassava: The Drought, War and Famine Crop in a changing World'. Sustainability 2:3572-3607.

CIAT (1980). Cassava Program: Annual Report 1979. Centro Internacional de Agricultura Tropical, AA 67-13, Cali, Colombia.

Ekanayake IJ (1996). Procedures for growth analysis of cassava. Procedures Manual, IITA, Ibadan, Nigeria. First edition. P. 28.

Ekanayake IJ, Dixon AGO, Asiedu R, Izac A-M N (1994). Improved cassava for Inland valley agro-ecosystems. In: Akoroda MO (ed.) Root Crop for Food Security in Africa: Proc. of fifth Triennial Symp. of the Intern. Soc. for Tropical Root Crops- Africa Branch held at Kampala, Uganda. Ibadan: IITA/ International Society for Tropical Root Crops, pp. 204-208.

Ekanayake IJ, Dixon AGO, Porto MCM (1996). Performance of various cassava clones in the dry savannah region of Nigeria. In: Kurup CT, Palaniswamy MS, Potty VP, Padmaja G, Kabeerathumara S, Pillai SV (eds.), Tropical Tuber Crops: Problems, prospects and future strategies, Lebanon, USA: Science Publishers, Inc pp. 207-215.

El-Sharkawy MA (1993). Drought-tolerant cassava for Africa, Asia and Latin America. BioSci. 43:441-451.

El-Sharkawy MA, Hernandez ADP, Hershey C (1992). Yield stability of cassava during prolonged mid-season water stress. Exp. Agric. 28: 165-174.

Fukai S, Alcoy AB, Llamelo AB, Patterson RD (1984). Effects of solar radiation on growth of cassava (Manihot esculenta Crantz). I. Canopy development and dry matter growth. Field Crops Res. 9:347-360.

Indira P (1996). Leaf area index and tuber yield in cassava as influenced by the time of application of nitrogen. In: Kurup CT, Palaniswamy MS, Potty VP, Padmaja G, Kabeerathumara S, Pillai SV (eds.), Tropical Tuber Crops: Problems, prospects and future strategies, Lebanon, USA: Science Publishers, Inc., pp. 219-226.

Irikura Y, Cock JH, Kawano K (1979). The physiological basis of genotype-temperature interactions in cassava. Field Crops Res. 2: 227-239.

Izac A-MN, Swift MJ, Andriesse W (1991). A strategy for inland valley agro-ecosystems research in East and Central Africa. RCMP Research Monograph No. 5, Ibadan, Nigeria: IITA, P. 24.

Jalloh A (2003). The potential of inland valley swamps in contributing to food security in Africa. FoodAfrica, 5-9 May 2003, Cameroon. 
Jalloh M, Palada MC (1989). On-farm trials in Makeni, Sierra Leone. In: Resource and Crop Management Program (RCMP) 1987 Annual Report. Ibadan, Nigeria: IITA. pp. 177-179.

Jarvis PG, Morison JIL (1982). The control of transpiration and photosynthesis by the stomata. In: Jarvis PG, Mansfield TA (eds.) Society of Experimental Biology Seminar 8. Cambridge: Cambridge University Press, pp. 247-279.

Lahai MT, Ekanayake IJ (2009). Accumulation and distribution of dry matter in relation to root yield of cassava under a fluctuating water table in inland valley ecology. Afr. J. Biotech. 8:4895-4905.

Lahai MT, Ekanayake IJ (2010). Transpiration rate and leaf water potential as indices for cassava yield in inland valley ecology. J. Agric. Sci. Tech. 4:34-44.

Lahai MT, George JB, Ekanayake IJ (1999). Cassava (Manihot esculenta Crantz) growth indices, root yield and its components in upland and inland valley ecologies of Sierra Leone. J. Agro. Crop Sci. 182:239-247.

Lebot V (2009). Tropical root and tyber crops: cassava, sweet potato, yam and aroids. CABI publication. Amazon.com. P. 413.

Lenis JI, Calie F, Jaramillo G, Perez JC, Ceballos H, Cock JH (2005). Leaf retention and cassava productivity. Field Crops Res. 95:126134.

Mohamoud YM (1994). Effect of mound height and cassava cultivar on cassava performance under a fluctuating water table. Agric. Water. Managt. 26:201-211.

Moormann ER, Lal R, Juo ASR (1975). The soils of IITA. IITA Tech. Bull. No.3, Ibadan, Nigeria.

Njoku DN, Afuape SO, Ebeniro CN (2010). Growth and yield of cassava as influenced by grain cowpea population density in Southeastern Nigeria. Afr. J. Agric. Res. 5:2778-2781.
Nweke FI, Spencer DS.C, Lynam JK (2002).The Cassava Transformation: Africa's best-kept secret. East Lansing: Michigan State University Press. P. 273.

Okogbenin E, Ekanayake IJ, Porto MCM (1999). Effect of planting materials and soil moisture on cassava performance in the semi-arid Sudan Savannah belt of Nigeria. Afr. Crop Sci. J. 1:21-33.

Ramanujam T (1985). Leaf density profile and efficiency in partitioning dry matter among high and low yielding cultivars of cassava (Manihot esculenta Crantz). Field Crops Res. 10:291-303.

Ramanujam T, Indira P (1983). Canopy structure on growth and development of cassava (Manihot esculenta Crantz). Turrialba 33:321-326.

SAS Institute (1991) SAS/STAT User's Guide, Version 6, Fourth Edition. Cary, NC, USA: SAS Institute.

Sheriff DW, Muchow RC (1984). The water relations of crops. In: Goldsworthy PR, Fisher NM (eds.), Physiology of Tropical Field Crops. New York: John Wiley $\square$ Sons Ltd.

Tafur SM de, El-Sharkawy MA, Cadavid L.F, De-Tafur SM (1997). Response of cassava (Manihot esculenta Crantz) to water stress and fertilisation. Photosynthetica 34:233-239.z

Tan SL, Cock JH (1979b). Cassava plant forms and their associated morpho-physiological characters. MARDI Res. Bull. 7:55-69.

Tan SL, Cock JM (1979a). Branching habit as a yield determinant in cassava. Field Crops Res. 2:281-289. 